\title{
Spot Survey Leptospirosis dan Reservoar Yang Berpotensi Menularkan Di Kecamatan Kuwarasan Kabupaten Kebumen Tahun 2017
}

\section{Dewi Puspita N/ Dyah Widiastuti/ Corry Laura JS}

\section{PENDAHULUAN}

Leptospirosis termasuk salah satu zoonosis yang disebabkan oleh infeksi bakteri berbentuk spiral genus leptospira. WHO memperkirakan jumlah kasus leptospirosis $\geq 500.000$ kasus/tahun di seluruh dunia dengan insidensi di beberapa daerah $975 / 100.000$ penduduk. Sedangkan di Indonesia bersumber dari laporan 7 provinsi sebanyak 833 kasus, dengan CFR $7,44 \%$

Jawa Tengah merupakan salah satu provinsi endemis leptospirosis, bahkan pada tahun 2015 menduduki peringkat pertama kasus terbanyak Indonesia. ${ }^{2}$ Selama 5 (lima) tahun terakhir kasus leptospirosis dilaporkan terjadi di 20 kabupaten/kota di Jawa Tengah. Sampai dengan triwulan III 2016 angka kematian karena kasus leptospirosis di Jawa Tengah mencapai $21,84 \%$. Kabupaten Kebumen merupakan salah satu daerah baru yang melaporkan kasus leptospirosis pada tahun 2017. Sampai dengan pertengahan bulan Februari, jumlah kasus leptospirosis di Kabupaten Kebumen berjumlah 5 kasus dengan kematian sebanyak 2 kasus

Reservoar utama leptospirosis adalah rodensia khususnya tikus. Bakteri Leptospira terpelihara di hati dan ginjal tikus selama hidupnya dan dikeluarkan melalui urin dalam jumlah yang banyak. ${ }^{4}$ Penularan leptospirosis pada manusia terjadi secara kontak langsung dengan hewan terinfeksi Leptospira, atau secara tidak langsung melalui air terkontaminasi urin yang terinfeksi Leptosplra. Baken ini masuk ke dalam tubuh manusia melalui kulit yang terluka, terutama sekitar kaki, selaput mukosa di kelopak mata, hidung, dan selaput lendir mulut. ${ }^{5}$

Informasi tentang penularan dan jenis reservoar $d$ Kabupaten Kebumen belum pernah dilaporkan sebelumnya. Kajian ini bertujuan untuk mengetahu faktor risiko penularan serta keberadaan reservoar yang tertangkap dan berpotensi menularkan leptospirosis.
METODE

Penelitian ini merupakan studi observasional dengan desain potong intang. Lokasi penellian di Kabupaten Kebumen sedangkan penangkapan reservoar dilakukan d Desa Mangli Kecamatan Kuwarasan berdasarkan pada laporan kasus terakhir. Pengumpulan data dilakukan pada bulan Maret 2017 dengan wawancara kasus probable. Selain itu juga dilakukan penangkapan reservoa menggunakan perangkap hidup (single live trap) sebanyak 300 buah selama 2 malam berturut-turut, yang dipasang d lingkungan permukiman dan sekitarnya. Reservoar yang organnya untuk dilakukan pemeriksaan keberadaan bakter Ieptospira patogen dengan menggunakan PCR. Selaniutnya data dianalisis secara deskriptif dalam bentuk tabel dan gambar.

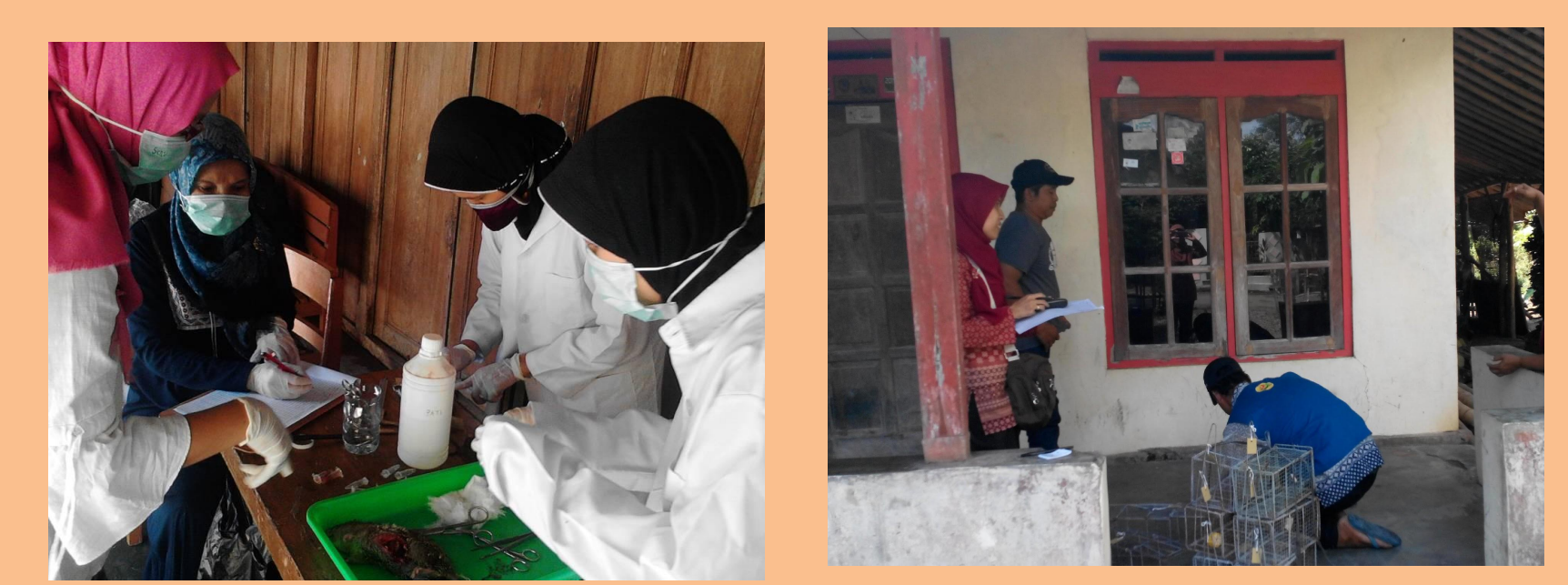

HASIL

Penderita leptospirosis yang berhasil di wawancarai sebanyak 9 orang, dengan 4 diantaranya diwakilkan keluarga (3 meninggal, 1 masih di RS). Semua penderita adalah laki-laki pada kisaran umur 31-40 tahun. Sebagian besar kasus leptospirosis $(78 \%)$ adalah petani/buruh tani dan terkena di sawah pada saat panen. Selain pekerjaan, faktor hilko ulama yang berkonthbusi yaitu adanya luka terbuka/lecet pada kani (100\%), lidak memakai APD pada saat bekerja $(88,89 \%)$ dan kontak dengan genangan air

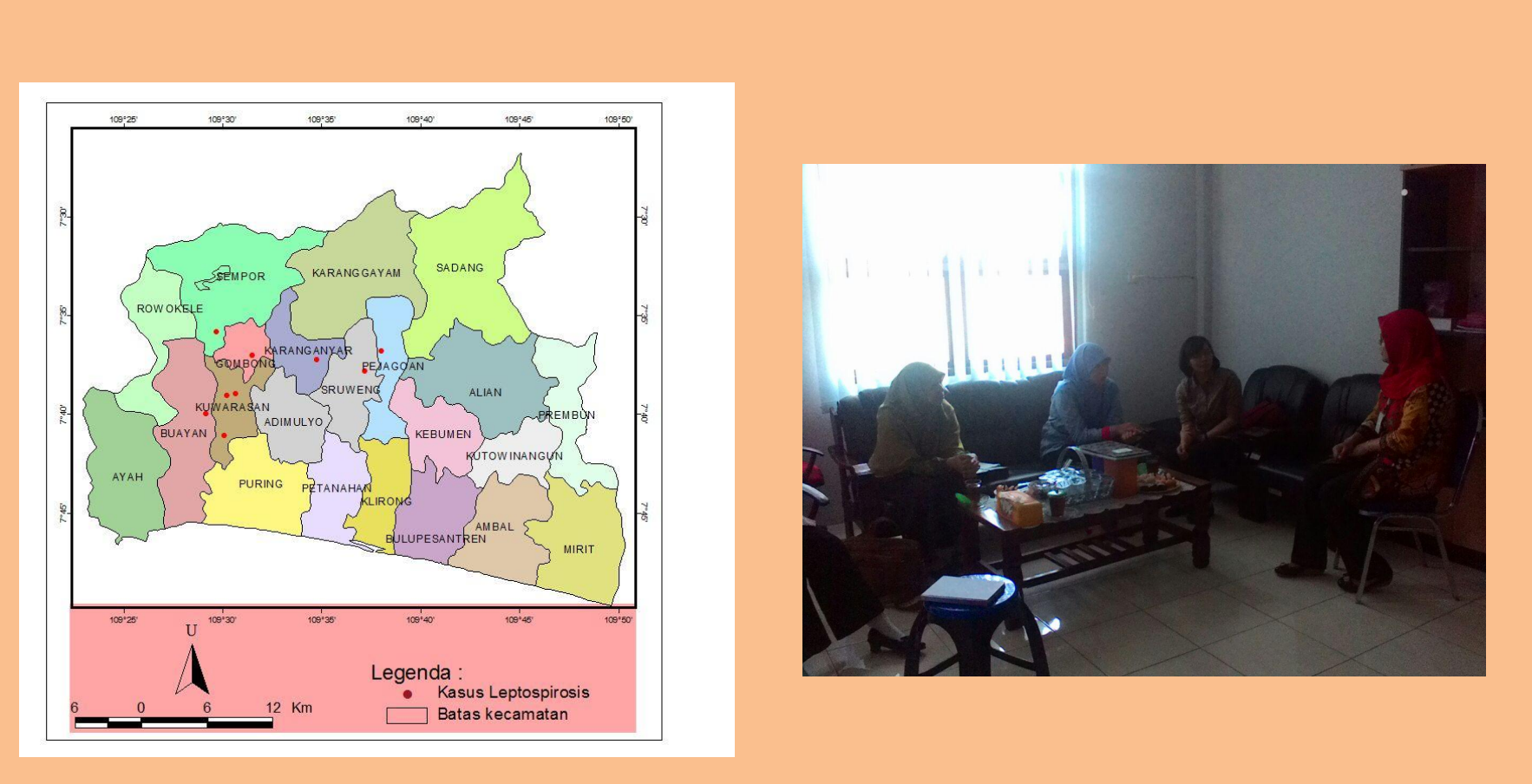

Reservoar yang tertangkap dalam penelitian ini adalah likus dan cecurut sebanyak 26 ekor, $68,23 \%$ betina, $61,53 \%$ tertangkap di luar rumah. Species tikus dan cecurut yang tertangkap yaitu Bandicota indica, Rattus tanezumi, Mus musculus dan Suncus murinus. Hasil pemeriksaan PCR menunjukkan 1 ekor tikus positif bakteri leptosira patogen dan ditemukan pada jarak > 30 meter dengan titik kasus. Walaupun kasus tidak berada di area tikus terinfeksi, tetap menjadi kewaspadaan karena jelajah tikus dapat mencapai 1 $\mathrm{km}$ bahkan lebih apabila terjadi kelangkaan pakan dan perpindahan. ${ }^{7}$ Dengan ditemukannya tikus positif di lokasi penelitian menunjukkan potensi risiko penularan leptospirosis setempat. Lokasi penderita berada $<30$ meter dari sawah yang memungkinkan adanya risiko penderita kontak dengan tikus dari sawah. Menurut Nurbeti, kasus leptospirosis mengelompok berdasarkan jarak kasus dengan sawah yailu sebagian besar kasus berada 0-100 meter dari sawah. ${ }^{8}$

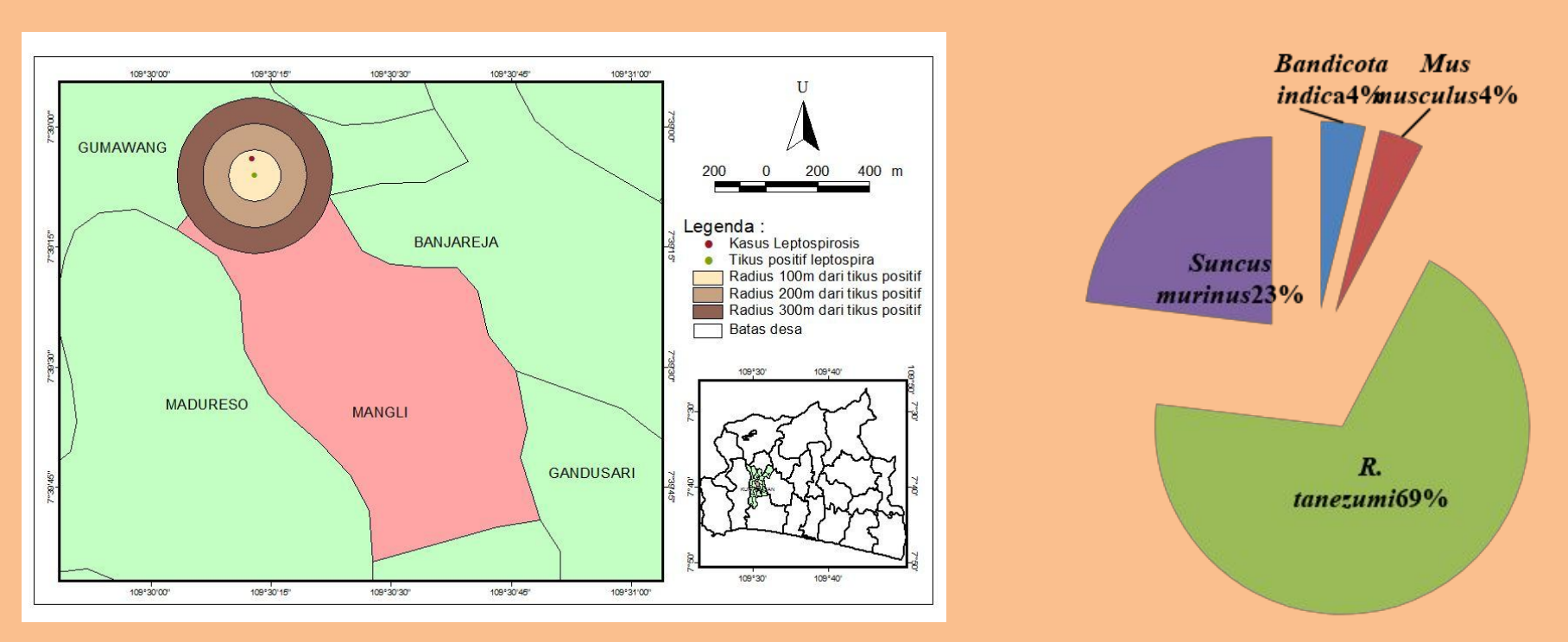

\section{KESIMPULAN}

Faktor risiko utama penularan leptospirosis : pekerjaan, adanya luka/lecet, tidak memakai APD saat bekerja dan kontak dengan genangan air dalam waku lama. Terdapat 1 ekor tikus peningkatan kewaspadan leptospirosis dan tindakan pengendalian reservor khususnya tikus dan cecurut baik di

\section{DAFTAR PUSTAKA}

Kemenkes RI. Profil Kesehatan Indonesia Tahun 2016. 2017

Dinas Kesehatan Prov. Jawa Tengah. Buku Saku Kesehatan Triwulan

3. Dinas Kesehatan Kabupaten Kebumen. Laporan Kasus Leptospirosis

Faine S, Adler B, Bolin C PP. Leptos
Melbourne Australia: MediSci 1999 .

Kusmiyati, Noor S, Supar. Leptospiross

Sholichah Z, Rahmawati. Sebaran Infeksi Leptospira Patogenik pada 列 Boyolali. Balaba. 2017;13(2):173-182

7. Nurbeti M, Kusnanto $\mathrm{H}$, Nugroho WS. Analisis Spasial Kasus Leptospirosis Di Perbatasan Kabupaten Bantul, Sleman Dan Kulon 